\title{
Research on the Microstructure and Mechanical Properties of High Ni Austenite Ductile Iron Prepared by Arc Deposition
}

\author{
Shuangfeng $\mathrm{Hu}^{1,2}$ and Xiujuan $\mathrm{Fu}^{2, *}$ \\ ${ }^{1} 1037$ Luoyu Road, Wuhan, China, Huazhong University of Science \& Technology \\ ${ }^{2} 693$ Xiongchu Avenue, Wuhan, Hubei,P. R. China \\ ${ }^{*}$ Corresponding author
}

\begin{abstract}
Based on the particles dispersive distribution method, arc deposition was developed to produce high $\mathrm{Ni}$ austenite ductile iron. The chemical composition of high $\mathrm{Ni}$ austenite ductile iron was designed, Modified welding machine (WSE-500 MIG, Homemade) was employed to carry out the arc deposition process, the influences of arc deposition parameters on the microstructure and mechanical properties of high $\mathrm{Ni}$ austenite ductile iron were discussed. Results indicated that the characteristics of spherical graphite were determined by the size and distribution of graphite particles in raw material. Under proper conditions, the mechanical properties of the arc deposition austenite ductile iron (tensile strength $R m \geq 350.0 \mathrm{MPa}$, yield strength $\mathrm{Rp0.2} \geq 255.0 \mathrm{MPa}$, elongation at break Ac $\geq 7.50 \%$, Vickers hardness, Hv190 245) were relatively better than the datum of the traditional casting samples obtained experimentally.
\end{abstract}

Keywords-arc deposition; high $\mathrm{Ni}$ austenite ductile iron; particles dispersed distribution

\section{INTRODUCTION}

Austenite ductile irons containing nickel from $18 \mathrm{wt} \%$ up to $36 \mathrm{wt} \%$ in ASTM are developed to meet the increasing demands for high strength ductile irons capable of operating at high temperatures in applications such as exhaust manifolds or turbocharger casings. These austenite ductile irons with complicate and intricate chemical compositions are prone to form various defects during casting because of its wide solidification temperature interval and high resistance of nodulizing, especially with high Ni content [1-6].

Electric arc is a gas discharge phenomenon with strong heating effect. Graphite with melting point $3773 \mathrm{~K}$ is a kind of temperature resistant material, even by arc combustion, the mass loss is very small[7].

Arc deposition, which makes use of the welding torch to gathering the coupling transferred arc beam and nontransferred arc beam, is actively used to synthesize extremely functional layers or fabricate three-dimensional parts layer by layer, and the layers are free of macro defects or inclusion [8]. A wide variety of super hard coatings, corrosion resistant coatings and complicated parts are produced by this technology including WC coating, $(\mathrm{Al}, \mathrm{Cr})_{2} \mathrm{O}_{3}$ coating, and $316 \mathrm{~L}$ spiral tube $[9,10]$. However, there seems no report about arc deposition ductile irons.
Based on the particle dispersive distribution method, arc deposition process was developed to produce the high $\mathrm{Ni}$ austenite ductile iron in order to avoid the casting defects in foundry production [11].

\section{EXPERIMENTAL}

\section{A. Selecting a Template (Heading 2)}

Based on D-5S austenite ductile iron in ASTM, the chemical composition of high $\mathrm{Ni}$ austenite ductile iron was designed and shown in Table 1 .

\section{TABLE I. CHEMICAL COMPOSITION OF HIGH NI AUSTENITE DUCTILE IRON}

\begin{tabular}{|c|c|c|c|}
\hline Element & Weight percentage (\%) & Element & Weight percentage (\%) \\
\hline $\mathrm{C}$ & $1.90 \sim 2.30$ & $\mathrm{P}$ & $\leq_{0.05}$ \\
\cline { 2 - 4 } $\mathrm{Si}$ & $4.80 \sim 5.00$ & $\mathrm{~S}$ & $\leq_{0.03}$ \\
\hline $\mathrm{Ni}$ & $34.0 \sim 36.0$ & $\mathrm{RE}$ & $\leq_{0.01}$ \\
\hline $\mathrm{Cr}$ & $1.60 \sim 1.70$ & $\mathrm{Fe}$ & bal \\
\hline
\end{tabular}

The raw material was graphite particles (200 250mesh), $\mathrm{Ni}(99.9 \%), \operatorname{Cr}(99.9 \%), \operatorname{Mn}(99.9 \%), 75 \% \mathrm{Si}-\mathrm{Fe}, \mathrm{DC} 01 \#$ steel, substantially free of Ni-Mg-Si-Fe nodularizer.

Modified welding machine (WSE-500 MIG, Home-made) was employed to carry out the arc deposition process, and the matched process parameters were calculated and shown in Table 2.

TABLE II. ARC DEPOSITION PROCESS PARAMETER OF HIGH NI AUSTENITE DUCTILE IRON

\begin{tabular}{|c|c|c|c|c|}
\hline $\begin{array}{c}\text { Input power } \\
(\mathrm{kW})\end{array}$ & $\begin{array}{c}\text { Arc } \\
\text { deposition } \\
\text { speed }(\mathrm{g} / \mathrm{min})\end{array}$ & $\begin{array}{c}\text { Shielding } \\
\text { gas }\end{array}$ & $\begin{array}{c}\text { Shielding } \\
\text { gas flow } \\
\text { rate }(\mathrm{L} / \mathrm{min})\end{array}$ & $\begin{array}{c}\text { Temperature } \\
\text { of substrate } \\
\left({ }^{\circ} \mathrm{C}\right)\end{array}$ \\
\hline $2.0 / 2.2 / 2.4 / 2.6$ & 9.5 & $\mathrm{Ar}$ & 16 & 180 \\
\hline
\end{tabular}

Specimens for test and examination were cut from the deposited layer. The phase qualitative analysis was performed using X'Pert PRO and Jade. Specimens for the metallographic examination were polished and etched by a mixture of $\mathrm{C}_{2} \mathrm{H}_{5} \mathrm{OH}+4 \% \mathrm{HNO}_{3}$ solution. The microstructures were examined using an Axiovert 200MAT optical microscope and a Quanta 200 environmental scanning electron microscope. At room temperature $(298 \mathrm{~K})$, the tensile tests were performed at a crosshead speed of $1.25 \mathrm{~mm} / \mathrm{min}$ using a universal materials 
testing machine, which was connected to a computer to draw the load-displacement curves and record the mechanical properties. Hardness test was performed using HVS-50Z digital Vickers hardness. Squared based diamond indenter (Angle 136 ), with $10 \mathrm{~kg}$ load and 10s duration was applied.

\section{RESULTS AND DISCUSSION}

When the input power was $2.0 \mathrm{~kW}$, the profile of the deposited layer which was under three-directional compressing stress was shown in Figure.1.

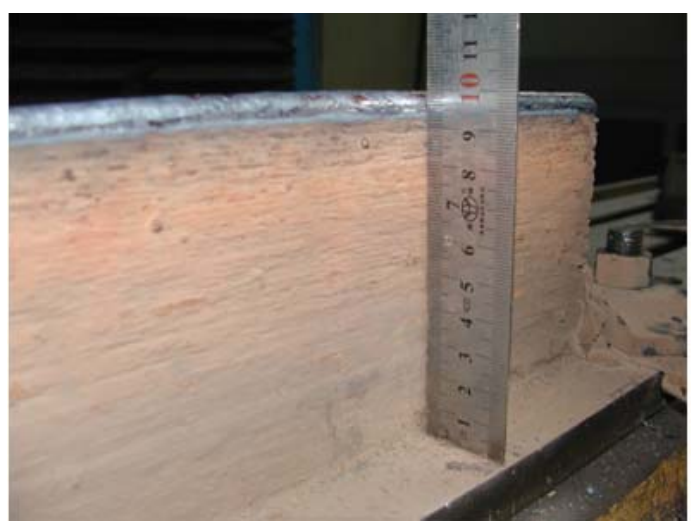

FIGURE I. PROFILE OF THE DEPOSITED LAYER

The surface of the deposited layer was structured and had metallic luster, without any defects such as porosity or cracks.

\section{A. Microstructures of the High Ni Ductile Iron}

The representative micro-structures of high Ni ductile iron samples produced by arc deposition are shown in Figure.2.
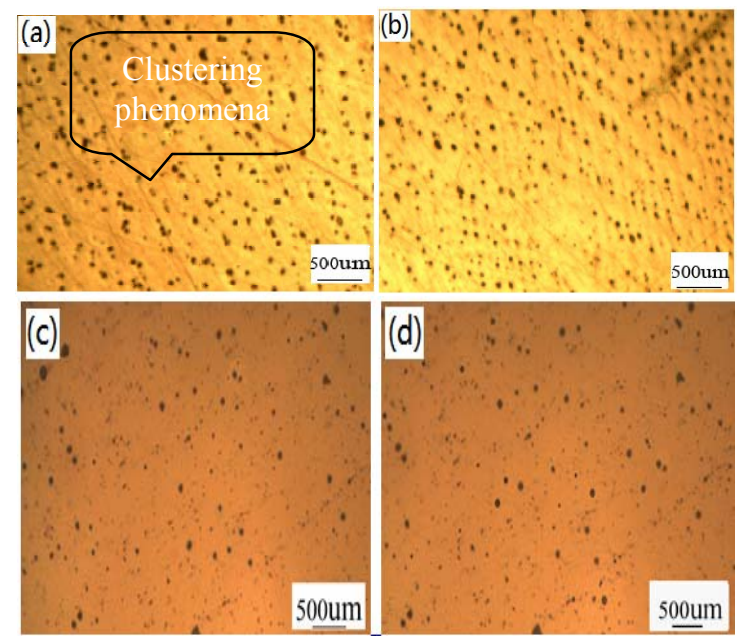

FIGURE II. METALLOGRAPHY OF HIGH NI AUSTENITE DUCTILE IRON (A) I=200A; (B) I=220A; (C) I=240A; (D) I=260A

Some black particles are uniformly distributed on the grain, Figure.3shows they are graphite particles. The average diameter of graphite particles in Figure. $2 a$ and $2 b$ is $60 u m$, and is roughly equal to that of the graphite particles in raw material. As the input power increases, the average diameter of the graphite nodules in Figure.2c and $2 \mathrm{~d}$ becomes smaller and more spherical.

It is clear that the distribution of graphite particles is random and some graphite particles are clustered together. As the particle size of the graphite particles is small (about 250mesh). Some graphite particles would be bonded together when mixing because of the molecular force, when these bonded particles run into the molten pool and showed the clustering phenomena.

The SEM micrograph of the high Ni ductile irons is shown in Figure.3.

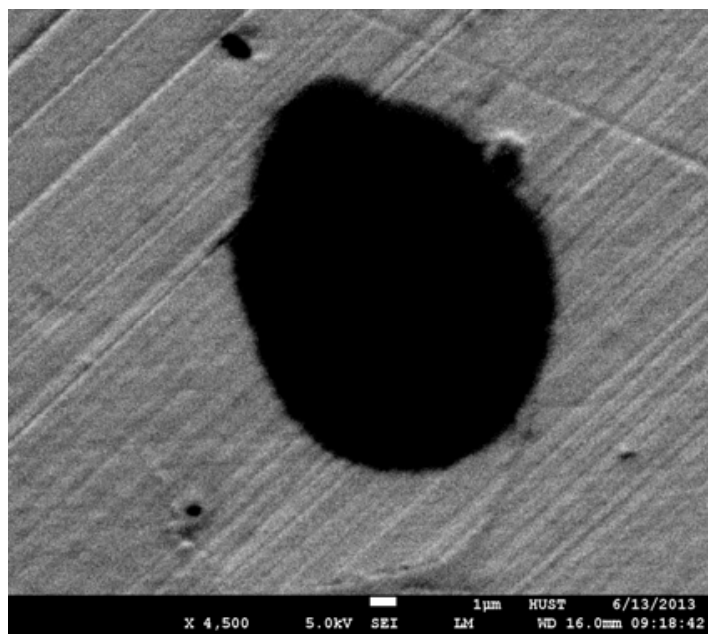

FIGURE III. SEM OF THE HIGH NI AUSTENITE DUCTILE IRON

Figure. 3 shows the graphite particle is spherical, due to the arc combustion effect, the sharp edge of the graphite particles was burning, the graphite particles are perfectly spherical, and the spheroidization rate level is above $90 \%$.

Between the graphite particle and the metallic matrix, there is a clear boundary in the interface, but there are no defects such as holes or cracks in the interface. As the graphite particle is hard to form chemical bond with metal, it is mechanical integration between them.

Figure. 3 shows no light spots in the centre of graphite particles, and no substance of graphite particles was found by XRD. In the cast ductile iron, the centre of the graphite nodule has light spots and contains many elements, including $\mathrm{Ni}, \mathrm{Mg}$, $\mathrm{Si}$, etc.

The phase of high $\mathrm{Ni}$ austenite ductile iron was analyzed by X-ray diffraction (XRD), results are shown in Figure.4.

The FeNi and Fe0.64Ni0.36 were observed from the XRD pattern, which indicated that regional segregation of $\mathrm{Ni}$ was existed. As there were graphite particles in the raw materials, amounts of graphite particles were reserved. Part of $\mathrm{C}$ and small mount of $\mathrm{Cr}$, $\mathrm{Si}$ and $\mathrm{Mn}$ dissolved in the matrix uniformly and formed solid solution, thus CFe15.1 and the complicate C-Cr-Ni-Fe were observed from the XRD pattern. As the concentration of free carbon atoms in molten pool was very low, the content of the iron carbides was much less than that by casting. 
Besides spherical graphite and iron carbides, the main phase of the deposited layer was austenite matrix.

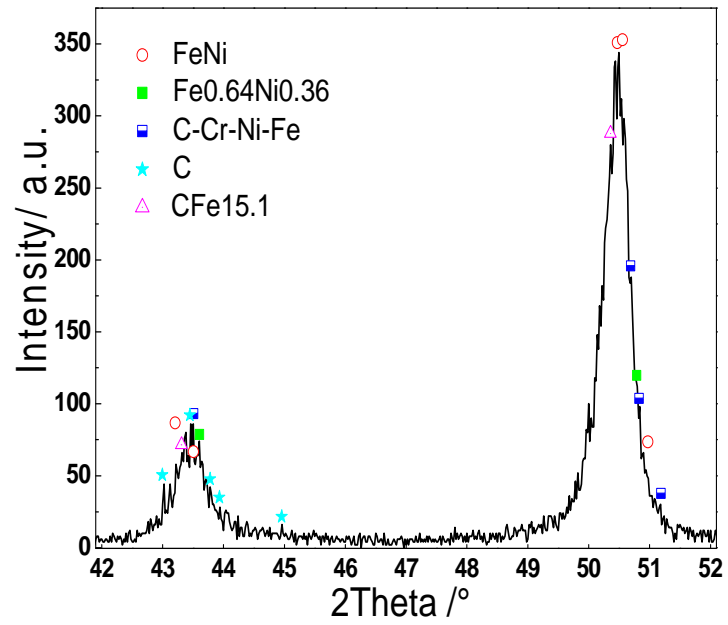

FIGURE IV. XRD PATTERN OF HIGH Ni AUSTENITE DUCTILE IRON

B. Mechanical Properties of High Ni Austenite Ductile Iron Vickers Hardness (HV) Analysis

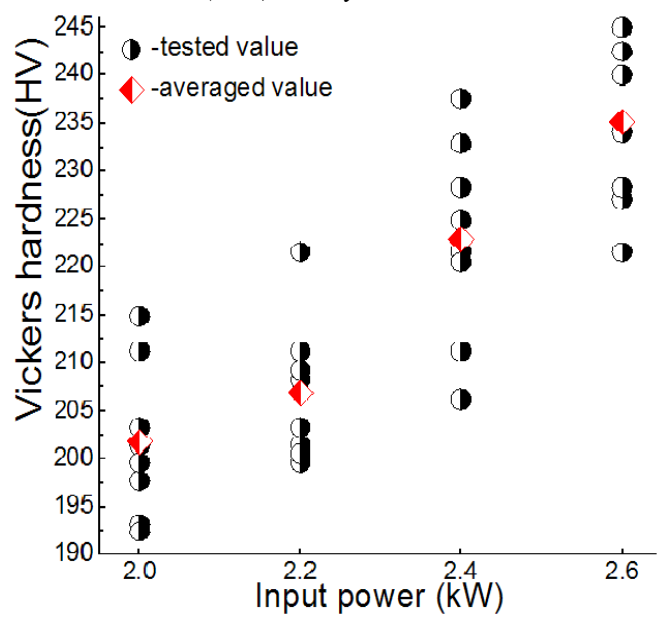

FIGURE V. VICKERS HARDNESS OF HIGH Ni AUSTENITE DUCTILE IRON PREPARED BY ARC DEPOSITION

Figure. 5 shows that the $\mathrm{HV}$ of high $\mathrm{Ni}$ ductile iron is between 190 and 245. As the input power increases, the average HV increases slightly, this may due to the increasing amounts of the carbides shown in Figure.2. Compared with casting, the HV of high Ni ductile iron by arc deposition is higher. When arc deposition, a higher cooling rate leads to the formation of a finer microstructure and the non-uniform temperature file causes large residual stress of the deposited layer, so the press resistance of the diamond indenter increases. It is consistent with the ref. [4].

\section{Tensile Properties}

The stress-strain curves of high $\mathrm{Ni}$ austenite ductile iron under different processing conditions are shown in Figure.6.

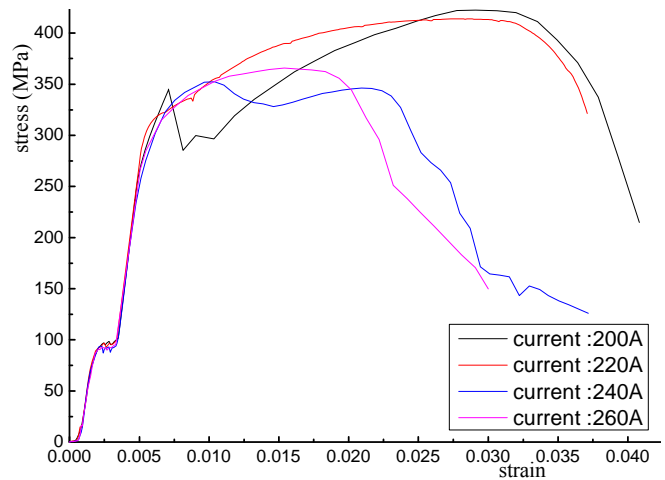

FIGURE VI. STRESS-STRAIN CURVE OF HIGH Ni AUSTENITE DUCTILE IRON

The tensile properties of high Ni ductile iron are shown in Table.3.

TABLE III. TENSILE PROPERTIES OF HIGH NI AUSTENITE DUCTILE IRON

\begin{tabular}{|c|c|c|c|c|}
\hline \multirow{2}{*}{$\begin{array}{c}\text { Input power } \\
(\mathrm{kW})\end{array}$} & \multicolumn{4}{|c|}{ Mechanical properties } \\
\cline { 2 - 5 } & $\mathrm{Rm} / \mathrm{MPa}$ & $\mathrm{Rp} 0.2 / \mathrm{Mpa}$ & $\mathrm{Ac}(\%)$ & Elastic Modulus/GPa \\
\hline 2.0 & 422.42 & 285.15 & 13.34 & 112.00 \\
\hline 2.2 & 413.83 & 280.57 & 11.27 & 106.66 \\
\hline 2.4 & 352.5 & 257.94 & 9.56 & 102.42 \\
\hline 2.6 & 369.64 & 260.54 & 7.58 & 99.48 \\
\hline
\end{tabular}

Figure.6 shows the influence of arc deposition power ranging from $2.00 \mathrm{~kW}$ to $2.60 \mathrm{~kW}$ on tensile properties of high $\mathrm{Ni}$ austenite ductile iron. As the input power increases, the tensile properties decrease slightly. This may due to the increasing contents of iron carbides and the interface of the austenite grains. The high temperature benefits the austenite grain growth and the reaction between graphite and irons, thus the amounts of iron carbides increase, which will dissever from the austenite matrix, on the other hand, the interface of the austenite grain will be enlarged, so the tensile properties decrease slightly.

Figure. 6 shows that when input power is under $2.20 \mathrm{~kW}$, tensile fracture is characterized by ductile fracture. When the input power exceeds $2.40 \mathrm{~kW}$, the fracture is mainly caused by the tearing of austenite phase, showing a feature of ductile fracture, and the elongation decrease obviously.

Compared with the conventional casting counterpart [2], arc deposition samples has higher mechanical properties, especially the yield strength and the tensile elongation are enhanced obviously. It has been commonly accepted that low rate of spheroidizing and shrinkage reduce the mechanical properties of casting samples. Under three-directional compressing stress, the deposited layer has compact and uniform microstructure, low apparent porosity, and based on the embedding method, the dispersed graphite particles can retard the growth of the austenite grain, thus the size of austenite grain and particles are refined obviously, therefore, the arc deposition sample has relatively higher mechanical properties than the conventional casting sample. 


\section{CONCLUSION}

(1) High Ni austenite ductile iron can be produced by arc deposition process without spheroidzing. The characteristics of spherical graphite were determined by the graphite particles in rare material. It is a mechanical combination between spherical graphite and austenite matrix in arc deposition ductile iron.

(2) Because of arc effects, the iron carbides are formed. As the input power increases, the content of iron carbides would increase and the tensile properties of the ductile iron would be deteriorated, in this research, when the input power is less than $2.2 \mathrm{~kW}$, The mechanical properties of the arc deposition samples are relatively better, and are considerably higher than the conventional casting ones.

\section{ACKNOWLEDGEMENT}

1) National Natural Science Foundation of China (No. 51575406)

2) Youths science foundation of Wuhan institute of technology (No.201201)

\section{REFERENCES}

[1] American Foundry men's society, Ductile Iron Handbook, Inc. Des Plaines, Illinois, 1993.

[2] ROGER COVERT, et al., Properties and Applications of Ni-Resist and Ductile Ni-Resist Alloys[M],A Nickel Development Institute reference book series No. 11 018, Nickel Development Institute; 1998.

[3] Du pixi,Huang shuzhe,Wangzhilin.Research on the microstructore and properties of high $\mathrm{Ni}$ austenite ductile iron[J], journal of jilin university of technology, 1986,(04): 45-54.

[4] NABIL FATAHALla, ALY ABUELEZZ, MOENES SEMEIDA. C, Si and $\mathrm{Ni}$ as alloying elements to vary carbon equivalent of austenitic ductile cast iron: Microstructure and mechanical properties[J]. Materials Science and Engineering; ; ,2009, 504(1-2):81-89

[5] WARRICK R J.SPHEROIDAL. Graphite Nuclei in $\mathrm{RE}$ and $\mathrm{Mg}$ Inoculated Iron[J]. AFS Cast Metals Research Journal,1966,2(3):722733.

[6] SUSIL K. PUTATUNDA .Development of austempered ductile cast iron (ADI) with simultaneous high yield strength and fracture toughness by a novel two-step austempering process[J]. Materials Science and Engineering: A,2001,315(1-2): 70-80.

[7] http://zh.wikipedia.org/wiki/\%E7\%9F\%B3\%E5\%A2\%A8.

[8] XIONG Xin-hong, ZHANG Hai-ou, WANG Gui-lan. Direct Rapid Prototyping of Metal Parts by Hybrid of Plasma Deposition[J], CADDM: 2006,16(02):18-22

[9] Li Lianjie, Gui Chibin. Dissolving behavior of tungsten carbide in surface welded using flux-cored wire[J]. Procedia Engineering. 2012, 27: 832-827.

[10] M. Pohler, R. Franz, J. Ramm.,etc. Cathodic arc deposition of $(\mathrm{Al}, \mathrm{Cr}) 2 \mathrm{O}$ 3: Macroparticles and cathode surface modifications[J]. Surface \& Coatings Technology: 2011: 1454-1460

[11] Zhang haiou, Hu shuangfeng,Wang guilan.A preparation method of nodular cast iron.China: 102268506A[P], 2011-12-07.

[12] SUN Daqia, ZHOU Zhenfeng,ZHA0 Zongju. Development of a New Electrode for Arc Welding of Austempered Ductile Iron(ADI)[J].J Mater Sci Technol.1992,8(6):401-405. 